\title{
COMMENT
}

\section{BANKS, TRUSTS AND INVESTMENT COMPANIES: THE COMMINGLED INVESTMENT FUND}

The banking industry has recently sought to take advantage of its financial expertise by extending its investment advisory services to the small investor-a field of diversified investment management heretofore dominated by mutual funds. ${ }^{1}$ This extension of financial services was made possible by the Comptroller's relatively recent revision of Regulation $9,^{2}$ which deals with the trust powers of national banks. The revision permitted banks to operate a modified common trust fund in essentially the same manner as an open-end investment company-by pooling small trust accounts in a single fund, the profits and losses of which are to be shared proportionately by each account. Not unexpectedly, the SEC has asserted its jurisdiction over these bankoperated funds. The SEC has taken the position that when banks enter the mutual fund business they should provide, and be subject to, the same investor protections which are required of mutual funds, and that these protections are not provided by the regulations issued by the authorities who are charged with regulating the banks. ${ }^{3}$

This Comment will examine three questions raised by the banksponsored fund permitted by the revised Regulation 9. (1) Does Regulation 9's commingled investment fund ${ }^{4}$ (CIF) qualify for both the Securities Act exemption for bank-issued securities ${ }^{5}$ and the In-

$x$ "Mutual fund" is the popular name for an open-end investment company, which offers to its stockholders diversification of investment and expert financial management by pooling the capital of the shareholders in a large fund in which each stockholder retains a pro-rata interest based on the amount of his contribution to the fund. Most mutual funds are "externalized," i.e., the fund employs separate entities to supply it with financial advice ("investment adviser") and underwriting services ("principal underwriter"). See generally Securities \& Exchange Comm'n, Public Policy Implications of Investment Company Growth, H.R. REP. No. 2237, 89th Cong., 2d Sess. 45-59 (1966) ; Securities \& Exchange Comm'n, Special Study of Securities Markets, H.R. Doc. No. 95, 88th Cong., 1st Sess., pt. 4, 95-99 (1963).

212 C.F.R. $\$ 9$ (1967). Regulation 9 was promulgated about six months after the power of the Board of Governors of the Federal Reserve System to regulate the trust powers of national banks was transferred to the Comptroller of the Currency. See text accompanying notes 18-20 infra.

3 Letter From William L. Cary to Senator Robertson, Nov. 27, 1963, reprinted in Hearings on S. 2704, Collective Investment Funds, Before a Subcommittee of the Senate Committee on Banking and Currency, 89th Cong., 2d Sess. 629, 631-32 (1966) [hereinafter cited as 1966 Hearings].

4 See note 22 infra and accompanying text.

5 Section 3(a) of the Securities Act of 1933 [hereinafter cited as Securities Act] provides:

Except as hereinafter expressly provided, the provisions of this title shall

not apply to any of the following classes of securities:

(2) [A] ny security issued or guaranteed by any national bank

48 Stat. $75^{\circ}$ (1933), 15 U.S.C. $\$ 77 \mathrm{c}(\mathrm{a})$. For an argument that this exemption is not grounded on sound policy considerations, see Comment, 52 VA. L. REv. 117 (1964). 
vestment Company Act exemption for common trust funds? ${ }^{6}$ (2) Does the operation of a CIF by a bank violate provisions of the Banking Act of 1933 (Glass-Steagall Act), prohibiting affiliation between banks and the securities industry? ${ }^{7}$ (3) Were exemptions properly granted by the SEC to First National City Bank of New York in order to allow it to operate a CIF under the Investment Company Act? ${ }^{8}$

\section{The Development of the Commingled Investment Fund}

Commingled Investment Funds have grown out of the common trust fund, a trust device created to remedy the banking industry's inability to administer small trusts of less than $\$ 200,000 .^{9}$ This inability arose from the need to charge an excessively high fee in relation to the income produced because the expense of managing a trust does not decrease to any significant extent with a decrease in the value of the assets; this is particularly true for trusts with a corpus worth less than $\$ 500,000$. $^{10}$ Because banks were loathe either to turn away business or to provide an unprofitable service for established customers, ${ }^{11}$ the industry developed the common trust fund. Instead of attempting to manage each trust individually, the assets of all the small trusts were lumped together into one "common" fund, which was then treated for investment purposes as a single trust corpus. The

6 Section 3(c) of the Investment Company Act of 1940 provides:

$[N]$ one of the following persons is an investment company within the meaning of this title:

(3) [A] ny common trust fund or similar fund maintained by a bank exclusively for the collective investment and reinvestment of moneys contributed thereto by the bank in its capacity as a trustee, executor, administrator, or guardian ... .

54 Stat. 797 (1940), 15 U.S.C. \$ 80a-3(c) (1964).

7 Section 16 of the Banking Act of 1933 (Glass-Steagall Act) prohibits a bank from underwriting any issue of securities or stock. 48 Stat. 184 (1933), as amended, 49 Stat. 709 (1935), 12 U.S.C. $\$ 24$, para. 7 (1964). Section 20 prohibits a bank from being affiliated with any underwriter. 48 Stat. 188 (1933), as amended, 49 Stat. 704 , 707 (1935), 12 U.S.C. $\$ 377$ (1964). Section 21 prohibits organizations in the securities business from accepting deposits of money subject to check or pass-book withdrawal. 48 Stat. 189 (1933), 12 U.S.C. $\$ 378$ (1964). Section 32 prohibits any person from serving in the dual capacity of officer, director or employee of both a bank and a firm in the securities business, unless the Board of Governors should find that an exemption from this provision would not unduly influence the bank's investment policies or advice. 48 Stat. 194 (1933), as amended, 49 Stat. 709 (1935), 12 U.S.C. \& 78 (1964).

8 See First Nat'l City Bank, SEC Investment Co. Act Release No. 4538 (March 9, 1966) reprinted at 1966 Hearings 81.

1966 Hearings 83.

10 This sum was once the suggested maximum for commingling. Wolfe, Wider Horizons for Common Trust Funds, 101 TRUSTS \& EsTates 1075, 1076 (1962). It is also the smallest managing agency account which the First National City Bank of New York considers it economical to accept. First Nat'l City Bank, SEC Investment Co. Act Release No. 4538 (March 9, 1966), reprinted at 1966 Hearings 81, 83.

11 Occasionally banks would administer uneconomically small trusts for the benefit of substantial customers of other divisions of the bank. Cf. Common Trust Funds -Overlapping Responsibility and Conflict in Regulation, Hearing Before a Subcommittee of the Honse Committee on Government Operations, 88th Cong., 1st Sess. 79 (1963) [hereinafter cited as 1963 Hearing]. 
participants shared in the earnings and losses in proportion to their contributions to the fund. In this way, a bank could achieve many of the economies of scale associated with a large trust despite the small size of each individual trust.

At the outset, the common trust fund required enabling legislation to overcome the common law rule prohibiting a trustee from commingling assets of different trusts. ${ }^{12}$ The first common trust fund was established in $1927,{ }^{13}$ but because of the financial panic which occurred soon thereafter and tax difficulties which arose from a successful attempt by the Commissioner of Internal Revenue to assess common trust funds with the corporate tax ${ }^{14}$ (later reversed by statute ${ }^{15}$ ), the growth potential of common trust funds was hampered initially. Only recently, when the banking industry observed the spectacular growth of mutual funds, and no doubt viewed the common trust fund as a vehicle which would allow it to share in the success of this rapidly expanding financial service, has the common trust fund become a controversial financial device.

The major obstacle facing the banking industry in attempting to enter the field was the steadfast refusal of the Board of Governors of the Federal Reserve System (Federal Reserve Board) to permit the use of the common trust fund device solely to provide the investor with the bank's financial management services. This prohibition was restated periodically in Federal Reserve Board rulings which also emphasized the restricted nature of advertising permitted under its Regulation $F^{16}$ The most recent of these rulings stated:

Authorization of revocable trusts for common trust fund participation should be preceded by particularly careful determination of the bona fides of their use and purpose to avoid improper use of the common trust fund as a medium attracting individuals primarily seeking investment management of their funds. ${ }^{17}$

The practical effect of these rulings was to prohibit banks from offering participation in the common trust fuad as a vehicle for investment.

12 Restatement (SeCOND), Trusts $\$ 179$ (1959). Statutes permitting common trust funds have been passed in the vast majority of states and the District of Columbia. A compilation of state law dealing with common trust funds appears at 1963 Hearing 169-76.

13 Some common trust funds had been established to hold mortgages as investments prior to the turn of the century, but they were validated by waivers of the common law no-commingling requirement, rather than statutory authorization. Saxon \& Miller, Common Trust Funds, 53 Gro. L.J. 994 (1965).

14 Brooklyn Trust Co. v. Commissioner, 80 F.2d 865 (2d Cir. 1936).

15 Internal Revenue Act of 1936, $\$ 169$, ch. 690, 49 Stat. 1708 (1936) (now INT. Rev. CoDe of 1954, \& 584). A comprehensive history of Brooklyn Trust Co. and $\$ 169$ appears in Saxon \& Miller, supra note 13, at 1003-09.

1642 Fed. Reserve Bull. 228 (1956); 41 Fed. Reserve Bull. 142 (1955); 26 Fed. Reserve Bull. 390, 393 (1940).

1742 Fed. Reserve Bull. 228 (1956). 
In December, 1960, the Federal Reserve Board proposed an amendment to Regulation $F$ which forbade the use of the common trust fund to manage revocable inter vivos trusts in which the settlor was the income beneficiary ${ }^{18}$ - a trust well-suited to do little more than obtain financial management services for its beneficiary-owner. Two years after this amendment was proposed, the banking industry suggested that "a more logical distribution of supervisory authority" 19 would be achieved by transferring the authority to regulate the trust powers of national banks from the Federal Reserve Board to the Comptroller of the Currency. Congress agreed. ${ }^{20}$

Soon after the enactment of this enabling legislation, the Comptroller convened a committee of banking industry representatives to propose amendments to Regulation 9 (the new name for Regulation $F$, adopted in its entirety by the Comptroller) which would provide for a more "up-to-date" ${ }^{21}$ regulation of the trust powers of national banks. Regulation 9, as amended on April 5, 1963, divided common trust funds into several categories, one of which, the CIF, is described as:

[A] common trust fund maintained by the bank exclusively for the collective investment and reinvestment of monies contributed thereto by the bank in its capacity as managing agent . . . .22

The amendment deleted the Federal Reserve Board's requirement that the common trust fund be used only for "bona fide fiduciary pur-

18 The Federal Reserve Board proposed to add the following language to Regulation $\mathbf{F}$ :

The funds of an inter vivos trust revocable by the settlor and providing for

the payment of the principal of the trust to the settlor's estate at his death may not be invested in a Common Trust Fund established and maintained under this section.

25 Fed. Reg. 12479 (1960).

19 Hearing on H.R. 12577 \& H.R. 12825 Before a Subcommittee of the House Committee on Banking and Currency, 87th Cong., 2d Sess. 19 (1962) (statement of F. A. Gunther on behalf of the American Bankers Association).

20 The authority was transferred by 76 Stat. 668 (1962), 12 U.S.C. \$92a (1964).

21 Remarks of James J. Saxon, Comptroller of the Currency, at the Midwinter Trust Conference of the American Bankers Association, February 4, 1963, Reprinted at 1963 Hearing 64-68.

2212 C.F.R. $\$ 9.18(a)(3)$ (1967). The two other categories of common trust funds created by the amendment are:

[A] common trust fund maintained by the bank exclusively for the collective investment and reinvestment of monies contributed thereto by the bank in its capacity as executor, administrator, guardian or trustee under a will or deed; 12 C.F.R. \& 9.18 (a) (1) (1967),

[A] fund consisting solely of assets of retirement, pension, profit-sharing, stock bonus, or other trusts which are exempt from Federal income taxation under the Internal Revenue Code;

12 C.F.R. $\$ 9.18$ (a) (2) (1967). Although all three types of common trust funds are designated "commingled investment funds" by Regulation 9, the term "CIF" is used here to refer only to the common trust fund defined in the text.

A comprehensive discussion of the securities laws issues raised by the pensiontype fund defined above appears in Mundheim \& Henderson, Applicability of the Federal Securities Lawes to Pension and Profit-Sharing Plans, 29 Inw \& Conresr. PRoв. 795, 819-37 (1964). 
poses." 23 This deletion caused the Commissioner of Internal Revenue to question the applicability of the pass-through treatment accorded common trust funds by section 584 of the Internal Revenue Code. ${ }^{24}$ After several conferences between the two agencies, the Internal Revenue Service ruled that

moneys received by a bank in its capacity as managing agent . . under a managing agency agreement expressly providing that such moneys are received by the bank in trust, when placed in a common fund with other similar funds, will be contributed to the common fund by the bank in its capacity as "trustee" as that word is used in Section 584 of the Code. ${ }^{25}$

A revised version of Regulation 9, published about ten months later, added to the definition of a CIF the words, inter alia, "under a managing agency agreement expressly providing that such monies are received by the bank in trust." ${ }^{26}$ Apparently the Comptroller did not desire to dispute the Commissioner's contention that a managing agency was not the trust relationship referred to in section 584 .

The SEC has contended that the CIF, whether operated by commingling trusts or managing agency accounts, is an investment company subject to registration under the Investment Company Act, and that the interest therein (participation) is a security subject to

2312 C.F.R. $\$ 206.17$ (a) (3) (1961) (terminated Oct. 12, 1962). Although Comptroller Saxon had stated that "no one has ever been able to explain satisfactorily that term [bona fide fiduciary purpose] to me," 1963 Hearing 67, its meaning was clarified in a ruling of the Federal Reserve Board which pointed out that "trusts created and used for bona fide fiduciary purposes are to be distinguished from trusts created by individuals primarily seeking the benefits to be derived from corporate fiduciary management." 41 FED. RESERVE Bull. 142 (1955). Compare the observation by Professor Scott that trusts can be classified by "a general division into trusts created for the purpose of distributing the bounty of the settlor, and trusts created for business purposes," 1 SCOTT, TRUSTS, $\$ 59$, at 514 (2d ed. 1956) with the statement of one of the members of the committee for revision of Regulation 9: "Now just what is a bona fide trust? . . No one in authority has defined it, and no one really knows - . Wolfe, Wider Horizons for Common Trust Funds, 101 TRUSTs \& Estates 1075, 1076 (1962).

24 INT. Rev. CoDe of 1954, §584(b), provides: "A common trust fund shall not be subject to taxation under this chapter and for purposes of this chapter shall not be considered a corporation."

25 Rev. Rul. 64-59, 1964-1 Cum. Bulc. 194.

26 29 Fed. Reg. 1719 (1964). The definition currently reads:

[A] common trust fund, maintained by the bank exclusively for the collective investment and reinvestment of monies contributed thereto by the bank in its capacity as managing agent under a managing agency agreement expressly providing that such monies are received by the bank in trust ... .

12 C.F.R. \$9.18(a)(3) (1967). A more complete comparison of Regulation 9 as originally promulgated and as amended in response to Rev. Rul. 64-59 appears at 1966 Hearings 599.

The concept of a managing agent holding funds in trist may have been sufficiently elusive to prompt First National City Bank to request and obtain an exemption from this requirement from the Comptroller when it proposed to operate a CIF. This exemption had no effect upon the CIF's tax status, since it qualified for pass-through treatment accorded mutual funds. INx. REv. CODE of 1954 \$ 851. 
registration under the Securities Act. ${ }^{27}$ Although the Comptroller has disagreed vehemently, ${ }^{28}$ the issue remains unresolved by the courts. ${ }^{28}$

\section{Applicability of Federal Securities Laws}

\section{The Securities Act}

In arguing that the participation in the CIF need not be registered under the Securities Act, the banking industry has presented two contentions: (1) because no certificate of participation is issued, ${ }^{30}$ the SEC is precluded from finding the existence of a security, ${ }^{31}$ and (2) assuming there is a security, it is exempt from registration under the act. ${ }^{32}$ The first of these arguments finds little support in the statute, which includes in the definition of a security "any interest or instrument commonly known as a security." 33 Since "instrument" includes all written documents, it would seem that "interest" includes unwritten obligations, assuming that statutory redundancy was not intended. This reading of the statute finds support in both the legislative history ${ }^{34}$ and recent cases. ${ }^{35}$ In any event, the agreement be-

271963 Hearing 9 (statement of William L. Cary, Chairman of the SEC). 28 Id. at 162-64 (statement of James J. Saxon, Comptroller of the Currency). 29 Neither agency has requested the Attorney General for a ruling. House Comm. on Gov't Operations, Connmon Trust Funds: Overlapping Responsibility and Conflict in Regulation, H.R. REP. No. 429, 88th Cong., 1st Sess. 3 (1963).

30 Regulation 9 provides that:

No bank administering a collective investment fund shall issue any certificate or other document evidencing a direct or indirect interest in such fund in any form.

12 C.F.R. $\$ 9.18(b)$ (13) (1967). Regulation F prohibited the issuance of a certificate which was negotiable or assignable, 12 C.F.R. $\$ 206.17$ (a) (3) (1961) (terminated Oct. 12, 1962); it has been suggested that the more restrictive approach taken by Regulation 9 was motivated by a desire to avoid the appearance of having issued a security. Comment, Regulation of Bank-Operated Collective Investment FundsJndicial or Legislative Resolution of an Administrative Controversy, 73 YALE L.J. 1249,1253 n.35 (1964).

31 See 1966 Hearings 33.

32 See note 5 supra.

33 Section 2(1) of the Securities Act provides:

The term "security" means any note, stock, treasury stock, bond, debenture, evidence of indebtedness, certificate of interest or participation in any profitsharing agreement, collateral-trust certificate, preorganization certificate or subscription, transferable share, investment contract, voting-trust certificate, certificate of deposit for a security, fractional undivided interest in oil, gas, or other mineral rights, or, in general, any interest or instrument commonly known as a "security", or any certificate or interest or participation in, temporary or interim certificate for, receipt for, guarantee of, or warrant or right to subscribe to or purchase, any of the foregoing.

48 Stat. 74 (1933), as amended, 15 U.S.C. \$77b(1) (1964).

34 A House Committee report states:

It is also intended to apply the act to interests commonly known as "securities" whether or not such interests are represented by any document or not. Thus the statute will apply to inscribed shares, and its provisions cannot be evaded by simply refraining from issuing to the subscriber any documentary evidence of his interest.

H.R. Rep. No. 1838, 73d Cong., 2d Sess. 39 (1934).

35 Roe v. United States, 287 F.2d 435 (5th Cir. 1961) (dictum); Woodward v.

Wright, 266 F.2d 108 (10th Cir. 1959); SEC v. Addison, 194 F. Supp. 709 (N.D.

Tex. 1961). There is no reason why the managing agency agreement itself could not 
tween the bank and the participant falls within the term "investment contract" ${ }^{36}$ as defined by the Supreme Court:
[A]n investment contract for purposes of the Securities Act means a contract, transaction or scheme whereby a person invests his money in a common enterprise and is led to expect profits solely from the efforts of the promoter or a third party, it being immaterial whether the shares in the enter- prise are evidenced by formal certificates or by nominal interests in the physical assets employed in the enterprise. ${ }^{37}$

The argument that the participations in the CIF are entitled to the Securities Act exemption for securities issued by banks ${ }^{38}$ has been refuted in a recent article discussing the securities law problems raised by the use of a common trust fund as a vehicle for the management of pension plan assets. ${ }^{39}$ The article advances two arguments relevant here: (1) the exemption extends only to securities which represent an interest in the profits derived from the business of banking, and (2) the definition of "issuer" which makes the bank the issuer of CIF participations ${ }^{40}$ could be construed as speaking "solely to the question of who has the issuer's liability and . . . not . . . [to] the question of whether a registration statement is required." 41 Both arguments appear equally applicable to the CIF, precluding the availability of the bank security exemption for the CIF participation.

serve as the written "instrument", if one were required. Furthermore, the Securities Act nowhere requires that the "security" be retained by the holder so that failure to provide the investor with a copy of the contractual agreement does not preclude a finding that the managing agency agreement is itself a security. 54 infra.

36 "Investment Contract" is included in the definition of "security". See note

37 SEC v. W. J. Howey Co., 328 U.S. 293, 298-99 (1946). The pre-Regulation 9 common trust fund, although an investment contract, was exempted from registration under $\S 4(2)$ of the Securities Act because sales of its participations were not made by means of a public offering. See 1963 Hearing 4 (statement of William L. Cary, Chairman of the SEC). Section 4(2) of the Securities Act has the effect of exempting from registration "transactions not involving a public offering." 48 Stat. 77 (1933), as amended, 15 U.S.C. $\$ 77 \mathrm{~d}(2)$ (1964). Section $4(2)$ is not applicable to participations in a CIF, since Regulation 9 permits them to be sold by public offering. See notes $49,52,55$ infra.

38 See note 5 sipra.

39 Mundheim \& Henderson, Applicability of the Federal Securities Laws to Pension and Profit-Sharing Plans, 29 LAW \& ConteMP. Prob. 795, 828-30 (1964).

40 Section 2(4) of the Securities Act provides in relevant part:

$[W]$ ith respect to certificates of interest or shares in an unincorporated investment trust not having a board of directors (or persons performing similar functions) or of the fixed, restricted management or unit type, the term "issuer" means the person or persons performing the acts and assuming the duties of depositor or manager pursuant to the provisions of the trust or other agreement or instrument under which such securities are issued. . .

48 Stat. 74 (1933), 15 U.S.C. \& 77b (4) (1964).

41 Mundheim \& Henderson, supra note 39, at 829 n.111. 


\section{The Investment Company Act}

The banking industry does not seem to contest the proposition that the CIF is an investment company, ${ }^{42}$ but rather claims an exemption from the provisions of the Investment Company Act under section 3(c) (3), which exempts

any common trust fund or similar fund maintained by a bank exclusively for the collective investment and reinvestment of moneys contributed thereto by the bank in its capacity as a trustee, executor, administrator or guardian. . . . ${ }^{43}$

The legislative history of this section indicates, however, that the near-dormant common trust fund considered by the Seventy-sixth Congress is not the CIF which Regulation 9 would permit to be aggressively merchandised in direct competition with mutual funds. The courts have ruled that the Investment Company Act is to be construed on the basis of the report on Investment Trusts and Investment Companies. ${ }^{44}$ A supplement to this report was devoted exclusively to common trust funds; ${ }^{45}$ it commented on their inactivity as follows:

Common trust funds have not participated in any active program of advertising and solicitation for participants in their funds. Only nine of the funds included in this survey published general booklets describing their business and recommending this use of the common trust fund medium. In instances where there was any solicitation for business it was of an informal nature where the officers of the banks or

42 Section $3(a)$ of the Investment Company Act defines "investment company" as any issuer which

(1) is or holds itself out as being engaged primarily, or proposes to engage primarily, in the business of investing, reinvesting, or trading in securities;

(3) is engaged or proposes to engage in the business of investing, reinvesting, owning, holding or trading in securities, and owns or proposes to acquire investment securities having a value exceeding 40 per centum of the value of such issuer's total assets (exclusive of Government securities and cash items) on an unconsolidated basis.

54 Stat. 797 (1940), as amended, 15 U.S.C. $\$ 80 \mathrm{a}-3$ (a) (1964). added.)

4354 Stat. 797 (1940), as amended, 15 U.S.C. \$ 80a-3(c) (3) (1964). (Emphasis

44 Prudential Ins. Co. of America v. SEC, 326 F.2d 383, 387 (3d Cir. 1964). See SEC v. Capital Gains Research Bureau, Inc., 375 U.S. 180 (1963). Compare the first sentence of the Investment Company Act which states that the act was passed "upon the basis of facts disclosed by the record and reports of the Securities and Exchange Commission made pursuant to section 79z-4 of this title [section 30 of the Public Utility Holding Company Act of 1935] . . ." 54 Stat. 789 (1940), 15 U.S.C. $\$ 80 \mathrm{a}-1$ (a) (1964).

45 Commingled or Common Trust Funds Administered by Banks and Trust Companies, H.R. Doc. No. 476, 76th Cong., 2 d Sess. (1939). 
trust companies discussed with their clients the comparative advantages and disadvantages of particular investment media.

. . [I]t appears that only a few common trust funds have issued participations in the last two years. ${ }^{46}$

This statement should be contrasted with a recent article by a senior vice president of a major New York bank which outlines techniques for aggressive selling of trust services. ${ }^{47} \mathrm{He}$ suggests instructing all officers of the bank concerning the characteristics of good prospects for the sale of trust services, ${ }^{48}$ and expanding bank mailing lists by utilizing the suggestions which these officers would then make. ${ }^{49}$ Other merchandising techniques include exhortations to employees to use the bank's trust services so that they might be able to make recommendations to acquaintances based on first-hand experience, ${ }^{50}$ and letters of commendation from high-ranking bank officers to employees and their supervisors for having secured substantial accounts. In connection with this outline for an effective sales campaign, it should be realized that the CIF practically obviates the problem of selecting customers; nearly anyone with a checking account is a good prospect.

It is unlikely that the minimal restrictions which Regulation 9 imposes on advertising ${ }^{51}$ will restrain to any significant degree the active merchandizing of the CIF. The bank's depositors and other customers provide a captive audience, which banks have not hesitated to solicit by including circulars with regular statements of account and other banking correspondence. Regulation 9's restrictions on adver-

$46 I d$. at 6.

47 Lovell, Trist New Business, 104 Trusts \& Estates 1164 (1965). For a description of a similar program, advocating the application of door-to-door selling principles to the merchandising of trust services, see Vunderink, Contest for Trust Business, 103 Trusts \& Estates 652 (1964).

48 It was suggested that this be done by means of a pamphlet, a copy of which was appended to the article. Lovell, supra note 47, at 1169. offering.

49 This practice, if used to promote the CIF, would probably constitute a public

[T] he transaction tends to become public when the promoters begin to bring

in a diverse group of uninformed friends, neighbors and associates.

Non Public Offering Exemption, SEC Securities Act Release No. 4552 (Nov. 6, 1962). Compare note 37 supra. supra.

50 Compare the excerpt from Securities Act Release No. 4552, quoted note 49

51 The sole restriction on advertising is mentioned only incidentally, in connection with a financial disclosure requirement:

[A] full [financial] report shall be furnished upon request to any person, and the fact of the availability of such material may be given publicity solely in connection with the promotion of the fiduciary services of the bank. Except as herein provided, the bank shall not advertise or publicize its collective investment fund (s).

12 C.F.R. $\$ 9.18$ (b) (5) (iv) (1967). 
tising would not prohibit including with such materials a reference to the availability of the bank's financial report for the CIF ${ }^{52}$

The restrictions imposed on the content of publicity concerning the CIF do not seem to present any real impediment to a bank which desires to promote its CIF services. Since the prohibition goes to the advertisement of the CIF itself- "the bank shall not advertise or publicize the collective investment fund(s)" ${ }^{5}$ - there appears to be nothing to prevent banks from continuing the aggressive advertising of their uncommingled managing agency accounts, ${ }^{54}$ either omitting the usual reference to minimum size, or including a squib such as "no account too small." Indeed, on its face, the regulation does not seem to prohibit the inclusion of the following remark:

Investors with more modest sums are invited to ask any branch office for a copy of our CIF financial report, which shows how even small sums can be profitably invested in equities managed by First Bank..$^{55}$

Although the above statement might be interpreted as a solicitation for the CIF in violation of the prohibition on advertising because it may do more than merely mention the CIF financial report, a more liberal construction may be entertained by the Comptroller. When a member of a congressional committee asked the Comptroller how he would rule on an advertisement which included the statement

We welcome this new opportunity the Comptroller's regulation would provide for us to put our trust investment facilities at the disposal of those of our customers with modest funds available for investment.

he declined to commit himself. ${ }^{56}$ It seems clear that promotional campaigns such as those outlined above would result in an investment vehicle far different from the near-dormant trust device which Congress exempted from the Investment Company Act.

The CIF is further distinguished from the pre-1940 common trust fund since there no longer may be a close personal relationship between the bank and the investor. A member of the banking industry

52 These circulars often publicize the more usual fiduciary services of the bank; hence a reference to the CIF would not violate the prohibition on advertising. See note 51 supra. This form of promotion would amount to a public offering under the Securities Act, since it would constitute advertising under the statute. See note 55 infra.

53 12 C.F.R. $\$ 9.18$ (b) (5) (iv) (1967).

54 See, e.g., New Yorker, April 8, 1967, p.26.

55 Such a solicitation would clearly constitute a public offering: "Public advertising of the offering would, of course, be incompatible with a claim of a private offering." Non Public Offering Exemption, SEC Securities Act Release No. 4552 (Nov. 6, 1962).

561963 Hearing 49. 
has suggested that the servicing of the CIF be done on a "machine-toman" basis; ${ }^{57}$ it is significant that Regulation 9 does not prohibit the use of the CIF as an automated vehicle involving no contact between bank and customer other than mailed annual statements. Lack of such individual attention deprives the investor of the opportunity to obtain that information about the management of his account which assures the adequate protection of his investment interests. ${ }^{58}$

When the Investment Company Act was passed, Regulation $F$ (Regulation 9's predecessor) was included in the common trust fund supplement to the Investment Company Study. ${ }^{59}$ This regulation restricted the operation of common trust funds by national banks to those operated solely for bona fide fiduciary purposes. ${ }^{60}$ Although it has been argued that the Regulation $F$ restrictions on common trust funds were not intended to be read into the Investment Company Act's exemption for common trust funds, ${ }^{\mathbf{6 1}}$ it seems unlikely that Congress intended to exempt a fund like the CIF, which is subject to a regulation which so departs from Regulation $F$ that the fund may become an investment vehicle of far greater financial significance than the 1940 common trust fund. ${ }^{62}$ This would seem particularly true where the fund could provide substantial unregulated competition for

57 Address by G. T. Lumpkin, Jr., 44th Mid-Winter Trust Conference of the American Bankers Ass'n, Feb. 5, 1963, reprinted at 1963 Hearing 114-20.

58 A necessary element to the "close personal relationship" is a substantial investment which enables the participant to demand information which the bank might otherwise be reluctant to collect and disclose. Consider a request by a CIF investor for a record of loans made by the bank to firms in which the bank has invested CIF assets-the cost of answering such queries in relation to the share of the management fee attributable to a single participation would enable the bank to justify its refusal to comply with the request. This would be particularly true where the size of the $C I F$ is such that the withdrawal of an individual participation would have a negligible effect on the size of the bank's advisory fee.

Compare the following from a landmark case interpreting the private offering exemption of $\S 4(2)$ of the Securities Act reproduced in note 37 sipra:

[T] he applicability of $\$ 4(1)$ [now $\S 4(2)$ ] should turn on whether the particular class of persons affected needs the protection of the Act. An offering to those who are shown to be able to fend for themselves is a transaction "not involving any public offering."

SEC v. Ralston Purina Co., 346 U.S. 119, 125 (1953). The employees here were not shown to have access to the kind of information which registration would disclose. Id. at 127 .

59 H.R. Doc. No. 476, 76th Cong., 2d Sess. 27-30 (1939).

6012 C.F.R. $\$ 206.17$ (a) (3) (1961) (terminated Oct. 12, 1962). See notes 16, 17,23 supra and accompanying text.

61 Marin, Common Trust Funds-Development and Federal Regulation, 83 BaNKING L.J. 565, 570 (1966).

62 Compare the statement of Mr. Justice Brennan in discussing whether a variable annuity and its underlying fund should be subject to federal securities regulation:

These controls [implemented by the Investment Company Act] may be largely irrelevant to traditional banks and insurance companies, which Congress clearly exempted; they were not investing heavily in equity securities and holding out the possibilities of capital gains through fund management; but where the investor is asked to put his money in a scheme for managing it on an equity basis, it is evident that the Federal Act's controls become vital.

SEC v. Variable Annuity Life Ins. Co., 359 U.S. 65, 79-80 (1959). See generally Comment, 115 U. PA. L. Rev. 600 (1967). 
investment companies subject to the restrictions of the Investment Company Act. ${ }^{\text {B3 }}$

Although the Comptroller feels that his periodic audits and regulatory restrictions provide protection sufficient ${ }^{64}$ to warrant the avoidance of dual regulation, ${ }^{65}$ it is not clear that this supervision satisfies the need for investor protection. The SEC maintains that standing alone, the regulatory and supervisory efforts of the Comptroller do not adequately protect the CIF investor because: (1) the Comptroller's regulation does not ensure that the investor can make an informed choice on the basis of full and adequate disclosure; ${ }^{66}$ (2) the Comptroller's primary concern in the regulation of banks is protection of depositors, rather than settlors and beneficiaries of trusts. ${ }^{67}$ The first of these criticisms seems amply borne out by a study of Regulation 9-neither the plan of operation nor a financial statement need be shown to the participant unless he specifically asks for them. ${ }^{68}$ There is no requirement that the investment objective of the CIF be disclosed under any circumstances. The material which is disclosed need not be arranged to facilitate comparison with the disclosure

03 Compare SEC v. United Benefit Life Ins. Co., 387 U.S. 202 (1967), where, in holding a "Flexible Fund Annuity" subject to the Securities Act, the Court said that such contracts

offer important competition to mutual funds . . . and are pitched to the same consumer interest in growth through professionally managed investment. Id. at 1562. The Court did not decide the question of whether an insurance company issuing securities was subject to the provisions of the Investment Company Act.

641963 Hearing 42-45. The Comptroller also argues that the local law of trusts provides protection to the participant over and above that provided by his office. Ibid. However, it should be noticed that many regulatory and common law protections can be waived by the investor, see note 72 infra and accompanying text, and that such rights as may exist afford no protection unless the investor can apprise himself of their accrual through full and complete disclosure. Compare note 58 supra.

Further, it should be noticed that, although none have been authorized as yet, CIF's which do not have participations in excess of $\$ 10,000$ in any one account may not be subject to any of the provisions of Regulation 9. 12 C.F.R. $\$ 9.18(\mathrm{c})$ (3) (1967).

65 It should be noticed that banks are presently subject to regulation by more than one agency, i.e., the Office of the Comptroller of the Currency and the Federal Reserve Board. The Chairman of the Federal Reserve Board has observed that banks engaged in more than one line of business, e.g., receiving deposits and operating mutual funds, can expect multiagency regulation, and that such regulation is not duplicative in any real sense. Hearings Before a Subcommittee of the Honse Committee on Interstate and Foreign Commerce on H.R. 8499, H.R. 9410, 88th Cong., 2d Sess. 104-05 (1964).

601963 Hearing 10-11. The Chairman of the SEC also argued that Regulation 9 does not require uniformity of disclosure from year to year by the same fund. Ibid.

As to whether the Comptroller's supervision is adequate to replace the disclosure required by federal securities legislation, the Chairman observed (in the course of hearings on whether bank stocks should be subject to the reporting requirements of the Securities Exchange Act) that

To say that bank regulation renders this disclosure philosophy unnecessary

is to say that bank regulation is an effective substitute for the free exercise of an investor's judgment.

Hearings on $S .1642$ Before a Subcommittee of the Senate Committee on Banking and Currency, 88th Cong., Ist Sess. 54-55 (1963).

671963 Hearing 9.

6812 C.F.R. $\S \S 9.18($ b) (1), 9.18(b) (5) (iv) (1967). 
required of mutual funds, ${ }^{69}$ with whom the CIF will compete directly for the investor's funds.

The orientation of the Comptroller's supervision toward protection of depositors is revealed in the Comptroller's Manual for Representatives in Trusts, ${ }^{70}$ which deals with the Comptroller's examination and audit of the trust departments of national banks. The manual treats trustee liability in terms of the necessity for securing adequate waivers and releases to protect the bank, rather than in terms of compensation to injured beneficiaries (this latter subject of compensation is not treated in the manual):

[Where the possibility of surcharge liability exists] valid written approvals [of questionable investments] should be obtained from beneficiaries with vested or contingent interests. Approval by a life tenant having a general power of appointment over the remainder interest should afford protection for the bank, unless the power to appoint is not exercised. Approval by a holder of a limited or special power of appointment, however, does not provide adequate protection except with respect to the power holder. Where such approvals are obtained from some but not all of the beneficiaries who have vested or contingent interests, there is no protection gained against the possible claims of those who did not join in the approvals. ${ }^{71}$

Hence it appears that the trust beneficiary's interest is not uppermost in the mind of the Representative in Trusts during the course of his examination, and no adequate substitute for the protection of federal securities law is provided.

A further illustration of Regulation 9's failure to focus upon protection of the CIF investor occurs in the area of self-dealing. At the outset it should be noticed that the limited protection Regulation 9 does afford can be waived by the participant, ${ }^{72}$ and that such waivers need

69 An example of SEC disclosure requirements can be found in the prospectus for the CIF sponsored by First National City Bank. Prospectus, Commingled Investment Account of First National City Bank (June 14, 1966).

70 This manual is reprinted in $3 \mathrm{CCH}$ FED. BANKING L. REP. $\llbracket 59,211-337$ [hereinafter cited as $\mathrm{CCH}$ Manual].

$71 \mathrm{CCH}$ Manual II 59,218. (Emphasis added.)

72 Section 12 of Regulation 9 provides in part

(a) Unless lazefully authorized by the instrument creating the relationship, or by court order or by local law, funds held by a national bank as fiduciary shall not be invested in stock or obligations of, or property acquired from, the bank or its directors, officers, or employees, or individuals with whom there exists such a connection, or organizations in which there exists such an interest, as might affect the exercise of the best judgment of the bank in acquiring the property, or in stock or obligations of, or property acquired from, affiliates of the bank or their directors, officers or employees.

12 C.F.R. \$9.12 (1967). (Emphasis added). Subsection (b) makes a similarly evadable prohibition of purchases from the CIF; subsection (c) allows the bank to include a provision in the agreement which obviates the prohibition against CIF purchases of securities issued by the bank or its affiliates. 
not be disclosed in any way other than by inclusion in the managing agency agreement. ${ }^{73}$ Even if the waiver were not included in the agreement, it has been pointed out that it is still possible for the bank to compel the CIF to retain an excessive proportion of its assets in the form of a cash deposit with the bank, and that the CIF may be used to shore up bank loans by causing it to purchase interests in a borrower which are subordinated to the bank's Ioan. ${ }^{74}$ Although the banking industry contends that the retention of cash balances is not a real problem, the Comptroller's Manual for Representatives in Trusts indicates that at least insofar as retention of deposits in the savings department of the bank is concerned, some questions remain:

Occasionally it will be found that a bank is carrying a substantial portion of its trust department funds as a time deposit in the commercial department without interest for the purpose of reducing the amount of reserve required to be carried. This practice is permissible, but the bank is required to make a periodic analysis of the individual accounts involved in order to determine the total amount which may be so deposited..$^{75}$

This provision seems to indicate that the bank would be free to deposit an unnecessarily large portion of the CIF assets in its savings department-which is exactly what the participant decided he did not want when he placed his funds in the bank's CIF rather than a savings account. The placement of CIF funds in a savings account also has the effect of subjecting the participant to two fees for the management of his funds-one is the CIF management fee and the other charge is imputed by the differential between the bank's lending rate and its interest rate on deposits. ${ }^{76}$ Should the bank cause its CIF to purchase a part of a new issue of a borrower in order to provide a cushion for a bank loan to that issuer, it is not clear whether Regulation 9 will have been violated. ${ }^{77}$ While it can be presumed that this problem is covered by the "overlay of trust law," it is unlikely that this abuse will be discovered by a CIF participant, since the bank is not required

$73 \mathrm{~A}$ sample CIF managing agency agreement containing this type of waiver appears at 1963 Hearing 184.

74 1963 Hearing 11-12 (statement of William L. Cary, Chairman of the SEC).

$75 \mathrm{CCH}$ Manual $\mathbb{1} 59,229$.

76 This double charge may be illustrated by the following example:

Assume the bank has been offered a $\$ 10,000$ bond returning 5 per cent annually. If purchased for the CIF, participants would receive $\$ 450$ per year ( $\$ 500$ minus a management fee of $1 / 2$ per cent of total assets, here $\$ 50$ ). If the bank's savings accounts pay 4 per cent and the bond were placed with the savings department, it would earn $\$ 400$ per year for depositors, or $\$ 100$ less than the amount received by the bank. But when CIF funds are placed in a savings account, participants are subject to both charges, and would receive only $\$ 350$ on their $\$ 10,000$ investment.

$7 \tau$ This may be a purchase from an organization "in which there exists such an interest ... as might affect the best judgment of the bank." See note 72 supra. The standard is somewhat vague. 
to disclose in its annual CIF report information regarding loans to corporations whose stock it holds through the CIF. The inadequacy of statements of income and financial condition as CIF disclosure devices seems clear. ${ }^{78}$

There also exists the possibility that the bank might acquire an equity holding for the purpose of obtaining banking business. ${ }^{79}$ Although Regulation 9 restricts holdings of any one issuer to ten per cent of the market value of the fund, ${ }^{80}$ there is no restriction on the fraction of the outstanding equity of any one issuer which a fund may acquire. Hence, the larger the fund the less meaningful the restriction becomes with regard to the bank's ability to influence the placement of the issuer's deposit and loan business. ${ }^{81}$

An additional undesirable practice which Regulation 9 permits is the use of the fund's assets to maintain a market in the bank's stock, or even to manipulate such a market, ${ }^{82}$ if the latter abuse escapes the attention of the SEC. These were time-honored practices, accomplished by means of the bank affiliate prior to the Glass-Steagall Act. ${ }^{83}$ Such use of the CIF allows the bank to assist large bank shareholders to unload a large block during a declining market by imposing the loss on the CIF; the fund's assets can also be used to buy out an intransigent bank shareholder at an attractive price.

78 Among the other problems of conflict of interest raised by the Chairman of the SEC was that of allocation of brokerage commissions generated by the CIF:

The fund has brokerage business to direct. We have learned that at present brokerage is often distributed by banks according to a formula which rewards those brokers who keep balances in the bank or have other business relations with the bank. This policy of the banks could lead to excessive portfolio turnover or to the fund not receiving the maximum benefit from its brokerage business.

1963 Hearing 12. The prospectus for the CIF established by First National City Bank expressly treats this problem, pledging to distribute brokerage so as to maximize the benefits to the participants.

79 Compare the following testimony offered by the Chief Counsel for the study which led to the Investment Company Act:

The investment banker may be impelled to have the investment company make an investment, not based upon investment quality of that investment, but because the particular investment may give him an "in" to get the banking business from the company whose securities the investment company bought.

Hearings on H.R. 10065 Before a Subcommittee of the Honse Conmittee on Interstate and Foreign Commerce, 76th Cong., 3d Sess. 110 (1940).

80 No investment for a collective investment fund shall be made in stocks, bonds or other obligations of any one person, firm or corporation if as a result of such investment the total invested in stock, bonds or other obligations issued or guaranteed by such person, firm or corporation would aggregate in excess of ten percent of the then market value of the fund . . . . 12 C.F.R. $\$ 9.18$ (b) (9) (ii) (1967). This restriction does not apply to pension CIF's, supra note 22, probably to accommodate the tendency of pension plans to invest in the securities of the employer.

81 The intent of the 10 per cent limitation seems to be to assure adequate diversification of the fund, rather than to prevent the use of the fund as a means of controlling an issuer's placement of bank business. Compare 12 C.F.R. $\$ 9.18$ (b) (9) (i) (1967) which limits to 10 per cent the fraction of any CIF (other than pension CIF's) which may be owned by any one participant.

82 See note 72 supra.

83 See note 96 infra. 
Thus, it would seem warranted to conclude not only that the exemption provided by section 3 (c) (3) is inapplicable to the CIF, in view of its legislative history, but also that it is undesirable on policy grounds to rely solely on the Comptroller's regulation for the protection of the small CIF investor. The essential similarity between the garden variety mutual fund and the CIF indicates that if different regulatory schemes were imposed, the more closely regulated mutual fund industry would bring pressure on the SEC or Congress to relax the regulatory standards applicable to it so that it might compete more effectively. ${ }^{84}$ The result would be a gradual lowering of standards, which is surely not in the public interest. ${ }^{85}$ This tendency would be encouraged when, as often happens, the Comptroller views himself primarily as a promoter for his industry, rather than its overseer. ${ }^{86}$

The SEC position that CIF's were subject to its jurisdiction did not have the effect of prohibiting banks from offering the CIF to the public-it merely meant that the CIF and the participation therein were required to be registered pursuant to the Investment Company Act and the Securities Act. Although the Comptroller originally maintained that it would be impossible for banks to operate CIF's if they were subjected to federal securities legislation, ${ }^{87}$ First National City Bank of New York (FNCB) felt that it could sponsor a CIF under the added regulation of the SEC if that agency could be persuaded to exempt the CIF from some of the provisions of the Investment Company Act. $^{88}$

\section{The Glass-Steagall Act}

The first step in registering FNCB's CIF was to ensure that operation of the CIF would not violate section 32 of the Glass-Steagall Act. This section prohibits any person from being employed simultaneously by a bank and an organization "primarily engaged in the issue, flotation,

84 This has been suggested as the probable result if the insurance industry were successful in avoiding SEC regulation. Mundheim, How the United Benefit Case May Affect the SEC's Chances in Congress, Institutional Investor, March 1967, p. 22.

85 Compare Comment, 115 U. PA. L. REv. 600, 616-17 (1967).

86 Compare the following statement on the advisability of resolving the dispute between the Comptroller and the SEC through legislation:

A consideration Congress should not overlook in deciding whether to allow the Comptroller to regulate these funds is the close affiliation of the Comptroller to banking interests. It may be argued that he cannot provide objective regulation in the investors' best interests because of his natural sympathy towards those he regulates.

Comment, 73 YALE L.J. 1249, 1264 n.123 (1964).

871963 Hearing 64-68. When the SEC indicated a willingness to exempt CIF's from certain provisions of the Investment Company Act, see note 145 infra, the Comptroller no longer found SEC supervision objectionable:

We contend that the regulations of our office and those of the SEC are complementary and we trust that they will be modified so as to eliminate duplicate reporting or other unnecessary activities on the part of banks while still maintaining all necessary protections.

1966 Hearings 131.

88 For a discussion of these exemptions, see text accompanying notes $132-47$ infra. 
underwriting, public sale, or distribution, at wholesale or retail, . . . of stocks, bonds or other similar securities." 89 It was conceivable that officers of the bank might be deemed to be working for both the bank and the CIF, and, further, that the sale of participations might constitute the issuance, underwriting or distribution of securities. ${ }^{.0}$ Since the Federal Reserve Board has jurisdiction to interpret section 32, it was necessary for FNCB to apply to the Board for a ruling that operation of its CIF would not violate that section. ${ }^{91}$ The Federal Reserve Board took what might be deemed a formalistic view of section 32 and construed it as prohibiting only employment by two separate entities. Hence the Board's holding that FNCB and its CIF were a "single entity" led to the conclusion that the prohibitions of section 32 were not violated. ${ }^{92}$ At the same time the Board declined to rule ${ }^{93}$ on the applicability of section 21 of the same act, which forbids a firm engaged in the business of issuing a security from accepting deposits. ${ }^{94}$ The Board's reluctance was based on a policy established in 1934, that it would not rule on statutes providing criminal penalties. $^{95}$

About two months after the Federal Reserve Board's ruling had been criticized on the floor of the House of Representatives for allowing banks to engage "directly" in an activity in which they could not engage "indirectly," 96 the Board released a legal memorandum ap-

89 Section 32 provides in relevant part:

No officer, director, or employee of any corporation or unincorporated association, no partner or employee of any partnership, and no individual, primarily engaged in the issue, flotation, underwriting, public sale, or distribution, at wholesale or retail, or through syndicate participation, of stocks, bonds or other similar securities, shall serve the same time as an officer, director, or employee of any member bank

48 Stat. $194^{(1933)}$, as amended, 12 U.S.C. $\$ 78$ (1964).

90 The Glass-Steagall Act does not define the word "security" as does \$2(1) of the Securities Act, supra note 33 ; hence it has been argued that qualification of the CIF participation as a security under the Securities Act is not determinative of the interpretation of the Glass-Steagall Act. Mundheim \& Henderson, Applicability of the Federal Securities Laws to Pension and Profit-Sharing Plans, 29 LAw \& ConTEMP. Prob. 795, 824-25 (1964).

91 In applying for an interpretative ruling under $\$ 32$, rather than an exemptive general regulation, FNCB may have been motivated by a desire to avoid conflict with the policy of the Board of Governors prohibiting association between mutual fund and bank personnel. See note 100 infra. However, this policy has been criticized as being excessively restrictive in view of the regulation afforded by the Investment Company Act, and it has been suggested that the exemptive provision in $\S 32$ be applied to this situation as well. Lehr, The Affiliation of Commercial Bank and Mutual Fund Personnel, 10 St. Lours L.J. 190 (1965).

92 The ruling is now codified. 12 C.F.R. $\$ 218.111$ (1967).

9312 C.F.R. $\$ 218.111$ (k) (1967).

9448 Stat. 189 (1933), as amended, 12 U.S.C. 378 (1964). The relevant language of the statute is set out in the text accompanying note 117 infra.

95 20 FED. Reserve Bull. 41 (1934).

${ }^{96}$ Statement by Representative Patman, 111 CoNG. REc. 27,211 (1965). The reference was to the fact that $\S 32$ prohibits interlocking directorates between banks and securities firms and thus prevented banks from engaging in the securities business "indirectly." To the extent that the bank and its CIF comprise a single entity, the Board's refusal to rule on $\$ 21$ (which prohibits banks from doing securities business "directly") validates the criticism. 
parently intended to buttress its ruling. ${ }^{97}$ This memorandum seems to rely upon a 1946 Supreme Court case, Board of Governors v. Agnew, ${ }^{98}$ for the single entity concept. Agnew involved several directors of a national bank who were also employed by Eastman Dillon, a member of the New York Stock Exchange. The Supreme Court upheld the Federal Reserve Board's determination that this dual employment violated section 32. Since Eastman Dillon did less than one-half of its business in the field of underwriting, the defendants had contended that section 32 was inapplicable, because the phrase "primarily engaged in . . . underwriting" 99 required that more than half of the firm's business consist of the enumerated activities. The Court held that "primarily" meant "substantially" and that Eastman Dillon's underwriting business was substantial enough to bring the prohibitions of section 32 into play. In the legal memorandum published to support the FNCB ruling, the Board read Agnew for the proposition that an "outside firm" must be involved before the statute is applicable. It is unlikely that this reading is accurate; the Agnew opinion nowhere relies on this principle, and it never discusses the question of when a firm is sufficiently "outside" to constitute a separate entity subject to the act's prohibitions.

The single entity concept ${ }^{100}$ does not provide much analytical assistance in determining whether bank sponsorship of the CIF creates conflicts of interest similar to those which section 32 was designed to eliminate. The exemptive provision of section 32 makes it clear that these conflicts of interest involved the effect which dual employment might have on the impartiality of the bank's investment advice, both for clients and its own portfolio:

In limited classes of cases . . . the Board of Governors of the Federal Reserve System may allow . . . [dual employ-

97 The memorandum is reprinted at 1966 Hearings 581-88.

98329 U.S. 441 (1947).

99 See note 89 supra.

100 The single entity concept appears to have originated in rulings by the Federal Reserve Board that a bank director could not be affiliated with an adviser to a mutual fund, if there was such a close connection between the adviser and either the fund itself or its principal underwriter that they constituted a single entity. See, e.g., 12 C.F.R. $\$ 218.107$ (1967). The concept's most recent application prior to the FNCB ruling occurred in a case in which a partner in a New York Stock Exchange firm desired to become a bank director. Before he applied to the Board for a ruling on whether his connection with the securities business disqualified him, the partner had obtained an exemption from the exchange rule requiring partners to have an interest in partnership subsidiaries proportionate to their interest in the partnership. Without the exemption from the exchange rule, the partner would have been required to own an interest in the partnership's underwriting subsidiary, which conducted business proscribed by $\$ 32$; ownership of this interest would clearly have prevented him from being a bank director. (A prior ruling by the Board held that participation in the business of executing securities transactions for the account of others, i.e., acting as a securities broker, did not constitute activity prohibited by $\$ 32$. 12 C.F.R. $\$ 218.1$ n.1 (1967).) The Board denied the application on the ground that the partnership and its subsidiary were a single entity, and that the partner was engaged in the prohibited activity by virtue of his interest in the partnership itself. 12 C.F.R. $\$ 218.108$ (1967). 
ment] by general regulations when in the judgment of the said Board it would not unduly influence the investment policies of such member bank or the advice it gives its customers regarding investments. ${ }^{101}$

The single entity concept permits all bank-operated CIF's to avoid the strictures of section 32. Such a result is clearly undesirable in view of the abuses to which CIF's may be subjected if they also escape SEC regulation. ${ }^{102}$

The 1935 amendments make it clear that section 32's scope nearly coincides with section $10(\mathrm{c})$ of the Investment Company Act of $1940 .^{103}$ Section $10(\mathrm{c})$ prohibits a majority of the members of an investment company's board of directors from being officers or directors of any one bank. A comparison of the legislative history of section 10 (c) with the text of section 32 of the Glass-Steagall Act, set out above, illustrates their near unity of purpose. ${ }^{104}$ In a committee report on the Glass-Steagall Act, the Senate Committee on Banking and Currency observed that

There seems to be no doubt anywhere that a large factor in the overdevelopment of security loans, and in the dangerous use of the resources of bank depositors for the purpose of making speculative profits and incurring the danger of hazardous losses, has been furnished by perversions of the national banking and State banking laws, and that, as a result, machinery has been created which tends toward danger in several directions.

(a) The greatest of such dangers is seen in the growth of "bank affiliates" which devote themselves in many cases to perilous underwriting operations, stock speculation, and maintaining a market for the bank's own stock often largely with the resources of the parent bank. ${ }^{105}$

10148 Stat. 194 (1933), as amended, 12 U.S.C. $\$ 78$ (1964). (Emphasis added.) That part of $\S 32$ which is omitted from the quotation in the text appears at note 89 supra.

102 The exemption from $\$ 10$ (c) of the Investment Company Act currently granted to FNCB, see text accompanying note 147 , infra, emphasizes the undesirability of a categorial exclusion. Should this exemption remain in force, the Board ought to impose $\S 32$ 's prohibitions on the bank; such flexibility is not possible under the present ruling. Such action by the Board would have the effect of requiring that the CIF board of directors have no members who are also officers or directors of the adviser bank.

10354 Stat. 806 (1940); 15 U.S.C. $\$ 80 \mathrm{a}-10$ (c) (1964). The text of $\$ 10(\mathrm{c})$ is set out at text accompanying note 147 infra.

$104 \mathrm{It}$ is curious to note that $\S 32$ of the Glass-Steagall Act (which was entitled in part "an Act to provide for the safer and more effective use of the assets of banks," 48 Stat. 169 (1933)) deals with investor protection, whereas the legislative history of the Investment Company Act describes $\S 10(c)$ as providing protection for banks. See text accompanying note 106 infra.

105 S. Rep. No. 77, 73d Cong., 1st Sess. 9-10 (1933). 
This concern for the strength of the banking industry and for purchasers of the investment advice represented by participations in the bank affiliate is mirrored by a statement made by the chief counsel for the Investment Company study (which laid the foundation for the 1940 Act) who pointed out that the section 10 (c) prohibition

was inserted not only on the basis of our study, but after conferences with the Federal Reserve Board. There were very undesirable consequences flowing from interlocking relationships between commercial banks and investment companies. Some of the worst abuses we had in the whole study arose out of that relationship and the Federal Reserve Board, as well as ourselves, felt that in the future, there should not be that close relationship. The adversities of the investment trust may have harmful effects on the bank such as runs on the bank. They are so intimately tied up. ${ }^{108}$

A practice made possible by the affiliation of bank and CIF which presents the greatest dangers to depositors and a strong banking system is that the bank may be tempted to make loans to corporations whose stock is held in the CIF portfolio, in the hope that such loans will improve the CIF's performance by causing a rise in the price of the corporate borrower's stock. ${ }^{107}$ The loan might be made in a case in which objective judgment might dictate otherwise, and would therefore impose an undue risk on bank depositors for the benefit of CIF participants. ${ }^{108}$

The abuse of the bank-CIF relationship which is injurious to CIF participants has three aspects, all of which have been discussed in connection with Regulation 9. ${ }^{109}$ To summarize, they are (1) purchases of voting stock for the CIF portfolio in order to acquire an influential position with potential purchasers of bank services; (2) shoring up bank loans by causing the CIF to purchase new issues of securities subordinated to notes or other securities held by the bank; (3) making a market for securities issued by the bank, including its own stock.

It should be clear from the practices described above that the single entity concept is inappropriate for determining whether section 32 has been violated. Use of this concept amounts to a categorical

108 Hearings on H.R. 10065 Before a Subcommittee of the House Committee on Interstate and Foreign Conmerce, 76th Cong., 3d Sess. 110-11 (1940).

${ }^{107}$ A loan may have the effect of increasing the price of a borrower's stock in at least three ways: (1) the loan will increase the leverage of the equity, thus increasing its value; (2) the loan will allow the borrower to expand, thus increasing its profitability; (3) news of such a loan may cause investors to rely on the lender's "obvious" confidence and bid up the stock, particularly if the lender is a large financial institution.

108 The principal abuse of depositors' funds connected with bank affiliates was the banks' practice of making loans directly to the affiliate to provide it with funds with which to speculate. Although this is now prohibited by 12 C.F.R. $\$ 9.18(\mathrm{~b})$ (8) (i) (1967), the practice mentioned in the text seems no less objectionable and considerably easier to conceal.

109 See text accompanying notes 70-83 supra. 
exclusion of all bank-operated CIF's, whether or not protection against abuse is afforded by adequate SEC regulation.

In regulating conflicts of interest in the banking industry, the Glass-Steagall Act pursues a policy of completely separating banks from the securities industry, thereby eliminating the possibility that such conflicts might arise. On the other hand, the Investment Company Act of 1940 permits the existence of potential conflict-of-interest situations, but closely regulates the conduct of persons who could become involved in such conflicts. ${ }^{110}$ The strictures of the Glass-Steagall Act which prohibit bank-operated CIF's no longer seem necessary, in light of the protection which the Investment Company Act provides investors. And as has been shown, bank depositors are adequately protected by the close scrutiny of the Comptroller of the Currency, who has their interests uppermost in mind in regulating trust powers of national banks. ${ }^{111}$ The proper procedure for the Board of Governors would seem to lie in the use of section 32's exemptive clause, referred to earlier. ${ }^{112}$ Reliance on the protection afforded CIF investors by the Investment Company Act (obviously not known to the Seventythird Congress which passed the Glass-Steagall Act) may justify an exemption for CIF's registered as investment companies with the SEC.

The propriety of such an exemption finds support in the language of section 10(c) of the Investment Company Act: in contrast with section 32's complete prohibition, section 10 (c) expressly recognizes the acceptability of dual employment, provided that it is restricted to a minority of the investment company's board of directors. ${ }^{113}$ The implication is clear that the scrutiny of an independent majority should be sufficient to ensure that the bank will not be "unduly influenced," as that phrase is used in the exemptive clause of section 32 .

Because the Federal Reserve Board had ruled that operation of a CIF by FNCB did not violate section 32, the Department of Justice declined to take any action, ${ }^{114}$ on the grounds that the Board's ruling

110 A discussion of the difference between the policy of the Glass-Steagall Act and that of the Investment Company Act appears in Lehr, The Affiliation of Commercial Bank and Mutual Fund Personnel, 10 St. Lours L.J. 190, 199-211 (1965).

111 See notes 70,71 supra and accompanying text. The following quotation from the Comptroller's Manual for Representatives in Trusts further demonstrates that the Comptroller views his responsibilities in administering trust powers of national banks primarily in the light of depositor protection:

The fundamental objective of a trust department examination is the assurance that the fiduciary activities of a National Bank are being executed in compliance with applicable Federal and local law and Regulation 9. When a National Bank trust department is thus operated, the beneficiaries and other parties at interest in the accounts being administered will have no just cause for complaint, and the bank will not be liable for surcharge. Therefore, the protection of the interests of the beneficiaries and other parties at interest is essential to the protection of the bank's depositors and shareholders.

$\mathrm{CCH}$ Manual đf 59,211 .

112 See notes 100-01 supra and accompanying text.

11354 Stat. $806(1940), 15$ U. S. C. $\$ 80 \mathrm{a}-10$ (c) (1964). Section 10(c) is set out in relevant part in the text accompanying note 147 infra.

114 Letter From Fred M. Vinson, Assistant Attorney General, to Orval L. DuBois, Secretary, Securities and Exchange Commission, Jan. 24, 1966, reprinted at 1966 Hearings 588. 
would preclude a successful prosecution under section 21.115 This position is difficult to support. Section 21 in no way depends upon the single entity concept as it is applied by the Board. The irrelevance of the Board's ruling on section 32 to questions arising under section 21 is emphasized by the fact that the Board had declined to rule on section 21, expressly reserving the question of whether it had been violated. Hence the Board's approval under section 32 should have no weight in ascertaining whether FNCB comes within section 21's prohibitions.

Because the Department of Justice declined to commit itself concerning section 21, the question of whether any sections of the GlassSteagall Act (other than section 32) had been violated, remained for private litigants to raise. In Investment Company Institute v. Camp, ${ }^{116}$ the Investment Company Institute alleged, inter alia, that Regulation 9 permitted the operation of a CIF in contravention of the restrictions laid down by sections 16, 20,21, and 32 of the Glass-Steagall Act.

Section 21 prohibits any organization engaged in the business of "issuing, underwriting, selling, or distributing, at wholesale or retail, or through syndicate participation, stocks, bonds, debentures, notes or other securities" from also accepting deposits of money. ${ }^{117}$ In comparison, section 32 prohibits any person employed by a bank from accepting additional employment with a firm which is primarily engaged "in the issue, flotation, underwriting, public sale, or distribution, at wholesale or retail, or through syndicate participation, of stocks, bonds, or other similar securities . . . ." 118 It is clear that the activity described in section 21 very closely parallels that described in section 32.118 The Federal Reserve Board has ruled that when an open-end investment company

is issuing or offering its redeemable stock for sale, it is "primarily engaged in the issue . . . public sale, or distribution, . . . of securities" and that section 32 of the Banking Act of 1933 [the Glass-Steagall Act], as amended, prohibits an officer, director or employee of any such company from serving at the same time as an officer, director or employee of any member bank. ${ }^{120}$

11548 Stat. 189 (1933), as amended, 12 U. S. C. \$378 (1964). The relevant portion of $\S 21$ of the Glass-Steagall Act is set out in the text accompanying note 117 infra.

116 Civil No. 1083-66 (D.D.C. 1966). (No opinion has been handed down as of Sept. 25, 1967.)

11748 Stat. 189 (1933), as amended, 12 U.S.C. $\$ 378$ (1964).

11848 Stat. 194 (1933), as amended, 12 U.S.C. \$ 78 (1964).

119 Both FNCB and the Comptroller argue that the activities described in $\$ 21$ are identical to those described in \$32. See 1966 Hearings 489-90; Memorandum of Points and Authorities for Defendant, p. 26, Investment Co. Institute v. Camp, Civil No. 1083-66, D.D.C. 1966.

12012 C.F.R. $\$ 218.101$ (1967). (Brackets in original.) 
In view of the similarity of the two sections, the above ruling indicates that a bank operating a CIF engages in the activity proscribed by section 21. Both FNCB ${ }^{121}$ and the Comptroller ${ }^{122}$ argued that the activities enumerated above describe the functions of an investment banker, and are limited in application to the underwriting business. Even assuming this to be true, the fact that participations represent an exercise of the bank's fiduciary powers and are not sold at a mark-up does not necessarily imply that sale of the participation does not involve underwriting. Pointing to the fact that participations in the CIF are sold at net asset value with no underwriting charge, FNCB argued that the absence of a "profit" implies that the bank is not engaged in underwriting. ${ }^{123}$ The lack of a mark-up notwithstanding, an indirect profit is derived from public distributions to the extent that they result in an increased management fee. Inasmuch as it is the management fee which spurs the bank to distribute CIF participations, it can hardly be argued that the bank derives no "profit" from its distributive activities.

Nor can the bank escape section 21's prohibitions by cloaking its merchandising activities in the form of a trust. Although section 21 may not have been intended to circumscribe banks' trust activity, ${ }^{124}$ it seems clear that it would prohibit the sale of participations in bank affiliates. It can scarcely be argued that section 21 would not be applicable if the affiliate were established in the form of a trust. In fact, as long as the CIF is susceptible to the same abuses as were imposed upon bank affiliates, ${ }^{125}$ the form in which the sponsor chooses to cast the investment vehicle should be irrelevant to the application of section 21 .

The preceeding analysis also leads to the conclusion that bank sponsorship of a CIF violates section 16 of the Glass-Steagall Act, which provides in part that a national banking association "shall not underwrite any issue of securities or stock . . . ." 126

Bank-sponsored CIF's can also run afoul of section 20 of the Glass-Steagall Act, which prohibits a bank from being affiliated with any organization which is

engaged principally in the issue, flotation, underwriting, public sale, or distribution at wholesale or retail or through syndicate participation of stocks, bonds, debentures, notes, or other securities . . . . ${ }^{127}$

1211966 Hearings 490.

122 Memorandum of Points and Authorities for Defendant, p. 26, Investment Co. Institute v. Camp, Civil No. 1083-66, D.D.C. 1966.

1231966 Hearings 490-91.

124 See Memorandum of Points and Authorities for Defendant, p. 26, Investment

Co. Institute v. Camp, Civil No. 1083-66, D.D.C. 1966.

125 These abuses are discussed in the text accompanying note 73 sipra.

12648 Stat. 184 (1933), as amended, 12 U.S.C. $\$ 24$, para. 7 (1964).

12748 Stat. 188 (1933), 12 U.S.C. § 377 (1964). 
However, the application of section 20 is restricted to cases where the bank is associated with an underwriting firm described by section 2(b) of the act. Such association occurs only when a bank controls the election of a majority of the CIF directors or if a majority of the CIF directors are directors of the bank. ${ }^{128}$ Since section $10(\mathrm{c})$ of the Investment Company Act prohibits a majority of the board from being affiliated with any one bank, ${ }^{129}$ and section $16(a)$ requires that directors be elected by the stockholders, ${ }^{130}$ conforming with section 10(c) of the Investment Company Act would preclude CIF's from violating section 20 of the Glass-Steagall Act.

\section{The Investment Company Act Exemptions}

Having secured the permission of the Federal Reserve Board to operate its CIF-entitled "Commingled Investment Account" 131_the last hurdle for FNCB to overcome was registration of the CIF with the SEC. The bank requested exemptions from several sections of the Investment Company Act designed to ensure that an investment company is not dominated by a bank or an investment banker. ${ }^{132}$ The exemptions which were contested subsequently before both the SEC ${ }^{133}$

128 Section 2(b) defines "affiliate" as including any corporation, business trust, association, or other similar organization-

(1) Of which a member bank, directly or indirectly, owns or controls either a majority of the voting shares or more than 50 per centum of the number of shares voted for the election of its directors, trustees, or other persons exercising similar functions at the preceding election, or controls in any manner the election of a majority of its directors, trustees, or other persons exercising similar functions; or

(2) Of which control is held, directly or indirectly, through stock ownership or in any other manner, by the shareholders of a member bank who own or control either a majority of the shares of such bank or more than 50 per centum of the number of shares voted for the election of directors of such bank at the preceding election, or by trustees for the benefit of the shareholders of any such bank; or

(3) Of which a majority of its directors, trustees, or other persons exercising similar functions are directors of any one member bank.

48 Stat. 162 (1933), 12 U.S.C. \$221a(b) (1964). Notice that subsection (2) would prevent the CIF from being used to provide the bank's shareholders with a vehicle for stock speculation as was done with bank affiliates prior to 1933. This abuse simply involved a bank loan to the affiliate which would use the proceeds to purchase highly speculative securities. Since only the loan would appear on the bank's financial statement, the nature of the bank's portfolio was effectively kept secret from depositors. The simultaneous ownership described in subsection (2), supra, assured that it was bank shareholders who reaped the speculative profits while the corporate form of the affiliate resulted in depositors' sharing the losses if the affiliate failed. See Willis, The Banking Act of 1933 in Operation, 35 ColuM. L. REv. 697, 701 (1935).

129 Relevant parts of $\$ 10$ (c) are set out in the text accompanying note 147 infra. 13054 Stat. 813 (1940), 15 U.S.C. \$ 80a-16(a) (1964).

131 As of February 28, 1967, First National City Bank's "Commingled Investment Account" had total net assets of $\$ 4,579,643.86$; the value of a unit of participation was $\$ 10.80$, up 8 per cent since June 2, 1966. Semi-Annual Report of the Six Months Ended February 28, 1967, Commingled Investment Account of First National City Bank. A minimum investment of $\$ 10,000$ is required. Prospectus, Cormmingled Investment Account of First National City Bank (June 14, 1966).

132 The application for the exemptive order is reprinted at 1966 Hearings 180-86.

133 The briefs and statements filed with the SEC in connection with the litigation are reprinted at 1966 Hearings 187-579. The opinion of the Commission, Investment Company Act Release No. 4538 (March 9, 1966), is reprinted at 1966 Hearings 81-90. 
and the Court of Appeals for the District of Columbia ${ }^{134}$ related to section 10 of the Investment Company Act ${ }^{135}$ which regulates the affiliation of directors of investment companies with other businesses.

In requesting an exemption from section $10(\mathrm{~b})(3),{ }^{136}$ which prohibits a majority of the board ${ }^{137}$ from being affiliated with the investment banking business, the bank pointed out that it might be considered an investment banker since it underwrote certain issues of government agencies. ${ }^{138}$ However, the bank argued that section $17^{139}$ of the Investment Company Act would prohibit the sale of these securities by FNCB to the Commingled Investment Account, and hence no investor protection would be lost if section 10 (b) (3) were not applied to the directors of the CIF. The SEC agreed with this argument.

The bank also sought to take advantage of section $10(d)$ 's ${ }^{140}$ lenient approach to affiliations between advisers and underwriters, and the investment companies which they sponsor. This section eliminates both the section 10 (a) ${ }^{141}$ requirement that no more than sixty per cent of the board of the investment company may be affiliated with the investment adviser, as well as the section $10(\mathrm{~b})(2)^{142}$ requirement that a majority of the board of directors of the investment company may not be employed by the principal underwriter. How-

134 National Ass'n of Sec. Dealers v. SEC, Civil No. 20,164, D.C. Cir. 1966. (Argument was heard on Jan. 4, 1967, but no opinion has been handed down as of Sept. 25, 1967.)

13554 Stat. 806 (1940), 15 U.S.C. $\$ 80 \mathrm{a}-10$ (1964). FNCB also requested exemptions from other, non-controversial sections (normally granted to investment companies in the process of organization) in order to allow it to conduct operations until it could hold the required CIF stockholders' meeting to approve certain of its actions. Other exemptions based on the obvious financial responsibility of the bank were also requested; both groups of exemptions were granted. First Nat'l City Bank, SEC Investment Co. Act Release No. 4538 (March 9, 1966), reprinted at 1966 Hearings 81-90.

13654 Stat. 806 (1940), 15 U.S.C. $\$ 80 \mathrm{a}-10$ (b) (3) (1964).

137 Because the Commingled Investment Account has not been incorporated, technically it has no board of directors. However, the bank has established a "Committee" charged with the functions usually performed by the board of directors of an investment company. In view of the act's definition of director, the members of the committee are subject to the restrictions placed upon directors by the act:

"Director" means any director of a corporation or any person performing similar functions with respect to any organization, whether incorporated or unincorporated . . .

54 Stat. 790 (1940), 15 U.S.C. $\$ 80 a-2(a)$ (12) (1964).

138 Section 16 of the Glass-Steagall Act, prohibiting underwriting by banks, supra note 118, contains exceptions for securities issued by certain government agencies. FNCB stressed the fact that these securities are considered suitable for unlimited investment by national banks. 1966 Hearings 211-12. The bank implied that the underwritten securities were not of the speculative character which, if sold to the $\mathrm{CIF}$, might endanger the fund.

13954 Stat. 815 (1940), 15 U.S.C. $\$ 80 a-17$ (1964). Regulation 9 makes a similar prohibition, but it is sufficiently qualified so as to make it considerably less rigorous than $\$ 17$ of the Investment Company Act. See notes 72 , 82 supra.

14054 Stat. 806 (1940), 15 U.S.C. $\$ 80 a-10$ (d) (1964).

14154 Stat. 806 (1940), 15 U.S.C. $\$ 80 \mathrm{a}-10$ (a) (1964).

14254 Stat. 806 (1940), 15 U.S.C. $\$ 80 a-10($ b) (2) (1964). 
ever, section 10 (d) imposes several conditions upon those who seek its benefits: at least one director must remain independent; no sales charge may be imposed upon purchases of interests in the fund; the fund must be open-end; a number of other requirements normally satisfied by funds operated merely as an adjunct to the investment advisory business must also be met. ${ }^{143}$ Applied to FNCB, section 10 (d) would have permitted four of the five CIF directors to be bank employees, rather than the maximum of three allowed by section 10 (a). In order to avail itself of the benefits of section 10 (d), FNCB requested an exemption from section 10 (d) (2)'s requirement that the advisor be registered with the SEC. The bank argued that its inability to comply with this provision was a "mere technicality" arising from the fact that banks are excluded from the definition of registrable investment advisors in the Investment Advisors Act. ${ }^{144}$ The SEC did not agree that this inability was a technicality which should be ignored and refused to grant the exemption, finding it not "necessary or appropriate in the public interest." 145 This ruling seems correct in light of the fact that the permissive approach taken by section 10 (d) was undoubtedly predicated on the fact that a bank could not qualify for it. Although section 10 (d) relaxes requirements found both in sections $10(a)$ and $10(b)(2)$, it pointedly ignores section $10(c)$, which prohibits a majority of the board of an investment company from being officers or directors of any one bank. ${ }^{146}$ Failure to relax section 10 (c)'s requirements can mean only that section $10(d)$ was not intended to be available to banks.

The crucial provision in the Investment Company Act from which FNCB sought an exemption was section $10(\mathrm{c})$, which requires that

no registered investment company shall have a majority of its board of directors consisting of persons who are officers or directors of any one bank. ${ }^{147}$

If imposed, section 10 (c) would limit to two the number of FNCB officers or directors who could serve as members of the five-man board of the Commingled Investment Account. An exemption from section 10 (c) leaves the composition of the board of directors to the section 10 (a) requirement that no more than sixty per cent-here three directors-may be affiliated with the bank.

The request for the exemption was justified on three grounds: (1) the CIF was not the type of investment company which section 10 (c) was intended to reach; (2) operation of the CIF did not violate

143 E.g., 54 Stat. 806 (1940), 15 U.S.C. $\$ 80 \mathrm{a}-10$ (b) (6) (1964).

14454 Stat. 847 (1940), as amended, 15 U.S.C. $\S 80 \mathrm{~b}-2(11)$ (1964).

1451966 Hearings 87.

14654 Stat. 806 (1940), 15 U.S.C. $\$ 80 a-10$ (c) (1964).

147 Ibid. 
the Glass-Steagall Act; (3) conflicts of interest were adequately regulated by the Comptroller's supervision. ${ }^{148}$ These contentions can be evaluated only in the light of the provisions and legislative history of section $6(\mathrm{c})$ of the Investment Company Act, ${ }^{149}$ from which the SEC derives its power to permit noncompliance with the act. Although a former chairman of the SEC has stated that this provision is sufficiently broad to enable the SEC to exempt the Commingled Investment Account entirely, ${ }^{150}$ it is clear from the legislative history that this power must be exercised judiciously and only under specified circumstances.

According to testimony introduced in the Senate Hearings on the bill which subsequently became the Investment Company Act, section 6(c) was incorporated into the act because

if some company came along-a company of a type which none of us has heard about-which in fairness ought not to be subject to this statute, we would not be able to do a single thing for it. I think it would be very unfortunate if the industry were made subject to too rigid a statute . . . ${ }^{151}$

The general counsel of the Investment Company study which led to the act, David Shenker, viewed the section in these terms:

148 In applying for the $\S 10$ (c) exemption, FNCB may have been motivated by the thought that a majority of the board must be affiliated with the bank in order to comply with the "single entity" analysis, see text accompanying notes 91-92 supra, or by a requirement under Regulation 9 that the bank must have "exclusive management" of the fund. 12 C.F.R. $\$ 9.18$ (b) (12) (1967). These justifications do not seem well grounded. The ruling by the Federal Reserve Board, supra note 92, does not expressly require that a majority of the board of the CIF must be affiliated with the bank; it merely notes that "at least one member of the committee would be entirely independent of the bank. . . " 12 C.F.R. $\$ 218.111(\mathrm{e})$ (1967). The ruling nowhere relies on the fact that a majority of the board must be affiliated.

It seems unlikely that the requirement that the fund be maintained by the bank would not be satisfied if the bank provides advisory and underwriting services in addition to a minority of the directors of the CIF. Clearly the CIF has no vitality without the bank's assistance. Even if the language of Regulation 9 quoted above implies the necessity for majority control, 12 C.F.R. $\$ 9.18$ (c) (5) (1967), allows the Comptroller to establish exemptions in cases where he deems it desirable to do so. Since any requirement for majority control arises from the Comptroller's regulation, it is preferable that the Comptroller exercise his exemptive power, rather than cause the SEC to grant an exemption from a Congressional Act. This analysis is supported by the consideration that depositors lose no protection when the board is independent, whereas CIF investors lose the substantial safeguard of scrutiny by an independent board if the bank retains majority control.

149 Section $6(\mathrm{c})$ provides

The Commission, by rules and regulations upon its own motion, or by order upon application, may conditionally or unconditionally exempt any person, security, or transaction, or any class or classes of persons, securities, or transactions, from any provision or provisions of this subtitle or of any rule or regulation thereunder, if and to the extent that such exemption is necessary or appropriate in the public interest and consistent with the protection of investors and the purposes fairly intended by the policy and provisions of this title.

54 Stat. 800 (1940), 15 U.S.C. \$ 80a-6(c) (1964).

1501963 Hearing 23 (statement of William L. Cary).

151 Hearings on S. 3580 Before the Subcomm. on Securities and Exchange of the

Senate Committee on Banking and Currency, 76th Cong., 3d Sess. 872-73 (1940)

[hereinafter cited as 1940 Hearings]. 
The only thing that this provision says is-if conditions exist or arise which manifestly are not within the legislative intent of this legislation, then the Commission should be in a position to exempt those in that situation, and the industry should not be required to go to Congress to get a statutory enactment to meet that specific situation. ${ }^{152}$

The Senate Report viewed section 6(c) in essentially the same termsallowing the exemption to be applied only to persons "who are not within the intent of the proposed legislation ...."153 This history indicates that to come under section $6(\mathrm{c})$ a company must be an investment vehicle not known to the 76th Congress nor intended to be stubject to the statute. ${ }^{154}$ Judged by either of these standards, FNCB's CIF does not qualify for exemption from section 10 (c).

In granting the exemption from section $10(\mathrm{c})$, the SEC argues that the CIF is a wholly new form of investment vehicle which could not have existed until 1963. ${ }^{155}$ It is not clear, however, that the CIF is distinguishable from the bank affiliate of the pre-1933 era. Both CIF's and bank affiliates represent large pools of liquid assets invested in accordance with advice supplied by their bank-sponsors. The abuses to which the CIF is subject have been described above; ${ }^{156}$ the imposition of these abuses on bank affiliates is thoroughly chronicled in hearings and reports which led to the Glass-Steagail Act and the Investment Company Act. ${ }^{157}$ The abuses common to both include shoring up bank loans through fund purchases of subordinated securities of the borrower ${ }^{158}$ and investment in potential customers in order to garner banking business, ${ }^{159}$ as well as various questionable transactions in the sponsor's stock. When the SEC seeks to rely on Regulation 9's prohibition of these practices in granting an exemption from section $10(\mathrm{c}),{ }^{100}$ it overlooks the fact that the prohibition may be

1521940 Hearings 197.

153 S. Rep. No. 1775, 76th Cong., 3d Sess. 13 (1940).

154 The SEC has stated the purpose of the section in terms which in practice may have the same meaning:

[T] he propriety of granting the relief which is sought largely depends upon the purposes of the section from which an exemption is requested, the evils against which it is directed, and the end which it seeks to accomplish.

Transit Inv. Corp., 28 S.E.C. 10, 15-16 (1948).

1551966 Hearings 85. Regulation 9 was revised in 1963 to permit banks to operate a CIF. See notes $22-23$ supra and accompanying text.

156 See text accompanying notes 72-83 supra.

157 See, e.g., note 105 sispra.

158 Securities \& Exchange Comm., Report on the Study of Investment Trusts \& Investment Companies, H.R. Doc. No. 707, 75th Cong., 3d Sess. 94 (1939). See note 74 sipra and accompanying text.

159 See Hearings on H.R. 10065 Before a Subcommittee of the Honse Committee on Interstate and Foreign Commerce, 76th Cong., 3d Sess. 110 (1940). See note 79 supra.

160 First Natl City Bank, SEC Investment Co. Act Release No. 4538 (March 9, 1966) reprinted at 1966 Hearings $81,86$. 
rendered nugatory by local law or provisions in the managing agency agreement. ${ }^{181}$

The SEC's reliance on section 17 of the Investment Company Act ${ }^{162}$ also seems unjustified. Congress was apparently unwilling to rely solely on section 17 to remedy these abuses, or section 10 (c) would not have been incorporated into the act. Indeed, it is not unlikely that the problem of detection was the primary motive for including section $10(\mathrm{c})$ in the act:

It has been urged that the prohibition against self-dealing which is contained in section 17, makes the prohibition of interlocking directors, contained in section 10, unnecessary; but the prohibition against self-dealing is not self-executing, and the history of American corporate finance plainly demonstrates that such prohibitions are very difficult to enforce. ${ }^{163}$

This difficulty, it was asserted, arises from the fact that

we have had prohibitions against self-dealing in corporation laws for generations, and self-dealing has gone on. It is very hard to stop it . . . because it is very easy to conceal. ${ }^{164}$

The testimony reproduced above indicates that Congress was unwilling to rely solely on administrative supervision to prevent self-dealing; an exemption predicated on SEC and Comptroller overseering functions would seem to subvert the intent of Congress as set out in section $10(\mathrm{c}) .^{165}$

While both FNCB and the SEC stress the fact that most bank affiliates known to Congress in 1940 were of the closed-end variety,

161 See note 72 supra.

16254 Stat. 815 (1940), 15 U.S.C. $\$ 80 \mathrm{a}-17$ (1964). Section 17 prohibits the following: most sales of securities by the underwriter to the fund absent specific approval by the SEC; joint enterprises between the fund and the underwriter; the acceptance of a commission for selling property to the fund by a person affiliated with the fund; the inclusion of provisions in company documents exculpating persons affiliated with the fund for acts done in bad faith.

1631940 Hearings 779 (testimony of E. Merrick Dodd, Jr.).

1611940 Hearings 762.

165 Of course, any argument seeking to find an expression of Congressional intent prohibiting an exemption in the language of the exempted section must meet the argument that

"purposes fairly intended by the policy and provisions" of the Act obviously means something more than a literal reading only of the provision from which an exception is desired. Otherwise, the existence of a provision prohibiting a transaction, which in every case under Section $6(\mathrm{c})$ is the very reason why an application for exemption is necessary, would also be the very reason for denying the application, thus making it impossible to resort to Section 6(c) to exempt a transaction from any provision of the Act.

Transit Inv. Corp., 28 S.E.C. 10, 17 n.20 (1948). This argument seems inapplicable where a section of the act is relied upon to show that Congress was unwilling to depend upon the same protections against self-dealing which the SEC finds adequate. Were the SEC to find, for example, that the problems involving self-dealing were nonexistent, the Transit argument would refute any contention that Congress desired that no exemption be granted simply because $\$ 10(\mathrm{c})$ expressed a policy of prohibiting bank domination of mutual funds. 
this fact does not distinguish them from the CIF. The closed-end characteristic was an historical accident in the sense that in 1940 most investment companies were closed-end; the potentialities of the openend fund simply had not been fully recognized by the financial world. Shoring up bank loans, maintaining a market in the bank's stock and investments designed to gain bank customers, seem no less difficult to impose upon a CIF which redeems its shares than upon a bank affiliate which does not; it is significant that the language of section $10(c)$ is in no way limited to closed-end funds.

If section $10(\mathrm{c})$ is not applied to the Commingled Investment Account, three of the five directors will be FNCB employees. It seems clear that the unaffiliated directors who comprise only a minority of the board exercise little or no influence on the conduct of the adviser to the fund. ${ }^{166}$ This impotence is no doubt caused in part by the fact that the majority controlling the board is often careful to select as independent directors only those persons who will not be overly critical. ${ }^{167}$ The ineffectiveness of unaffiliated directors is further aggravated by the minority's dependence on majority nomination to retain its position on the board. ${ }^{168}$ If section $10(\mathrm{c})$ is applied to the

168 Secturities and Exchange Comm'n, Public Policy Implications of Investment Company Grozeth, H.R. REP. No. 2337, 89th Cong., 2d Sess. 130-31 (1966) [hereinafter cited as SEC Mutual Fund Report], points out the inability of independent directors to reduce mutual fund management fees. However, ensuring the integrity of CIF operation by requiring adherence to generally recognized standards of fair dealing is to be distinguished from correction of an industry-wide failure to negotiate advisory fees at arm's-length. The failure of the independent directors in the area of management fees arises in part from the lack of a suitable alternative if the adviser declines to lower its fee:

The possibility of disrupting the fund's operations, the prospect of a bitter and expensive proxy contest, and the risk and uncertainty involved in replacing the entire fund management organization with a new and untested one, make termination of the existing advisory relationship a wholly unrealistic alternative in negotiations over advisory fees.

SEC Mutual Fund Report 131. Such a limitation is not present when the CIF board desires to require restitution of funds unfairly diverted to the bank-adviser; if threats do not succeed, the courts are open to a lawsuit demanding repayment.

${ }^{167}$ [I]f you are choosing an unaffiliated director or an independent director you are not going to choose anybody who is going to be too hard on you. You are going to tend to pick a friend of yours; . . . I have encountered two situations where a so-called unaffiliated or independent director happened to be the son of the leading stockholder of the adviser.

University of Pennsylvania Law School Conference on Mutnal Funds, 115 U. PA. L. REv. 669, 739 (1967) (remarks of Abraham L. Pomerantz).

108 Who picks the unaffiliated directors? The affiliated men pick the unaffiliated men. The men who need to be watched pick the watchdogs to watch them.

Ibid. Section 15(c) of the Investment Company Act, 54 Stat. 813 (1940), 15 U.S.C. $\$ 80$ (a) -15 (c) (1964) requires that a majority of the unaffiliated directors approve the management fee contract. The addition of one more independent director to the five-man Commingled Investment Account does not change the number necessary to approve the contract-two unaffiliated directors' votes are still needed. However, a majority of the board is normally necessary for the nomination of a slate of directors, and it is the control of this function which appears to be particularly necessary to ensure the independent supervisory judgment contemplated by $\$ 10(\mathrm{c})$ of the Investment Company Act. Although the initial selection of unaffiliated directors will be made by the bank, their working independence coupled with possible liability for overlooking bank transgressions should soon overcome any bias toward acquaintances in the bank as long as a majority of the board is independent. 
Commingled Investment Account, only two directors will be bank directors or officers; however, the difference in result is not merely that one more director will be independent of the bank. Rather, an independent board is more likely to ensure that the CIF's investment advice is not colored by the bank's self-interest. Portfolio transactions will be subject to closer scrutiny and directors are more likely to ask probing questions regarding bank dealings when a majority of the board is not beholden to the bank for its position. ${ }^{169}$ Transactions which otherwise might go unchallenged because of a board member's reluctance to appear as an officious gadfly, would no doubt trigger requests for the kind of disclosure required to conduct a mutual fund properly.

The real effect of an independent board is that the bank will be reluctant to enter into a transaction which it may have to explain later. It is this hesitancy, more than fear of board reprisals, that will ultimately protect CIF participants. As long as the CIF board is bank-dominated, the bank probably has no fear of embarrasing inquiries.

In view of the infrequency with which investment companies change advisers without the adviser's consent, ${ }^{170}$ the only thing which banks would lose by the creation of an independent board would be the opportunity to engage in transactions raising questions of conflict of interest. It seems unlikely that banks would find this loss objectionable.

Instead of continuing its campaign to obtain legislative exemption from SEC regulation, ${ }^{171}$ the banking industry might expend its lobbying efforts more judiciously by seeking Congressional amendment to the Glass-Steagall Act so that the operation of CIF's is expressly exempted from the prohibitions of sections 16 and $21,{ }^{172}$ provided that the SEC retains the regulatory scheme here outlined.

169 An unaffiliated director's request for information concerning bank transactions with issuers whose securities are held in the CIF portfolio would no doubt result in compliance. Compare the situation of the small CIF investor requesting the same information sketched in note 58 supra.

In connection with the need for effective disclosure in order to perform their supervisory functions, consider the suggestion that the unaffiliated directors should decide whether

in light of the many areas of conflicting interest between the fund and its adviser and underwriter or affiliated broker, the unaffiliated directors may consider it worthwhile for the fund to hire (either full-time or for special occasions) certified public accountants and counsel who are free at all times to represent only the interests of the fund.

Mundheim, Some Thoughts on the Duties and Responsibilities of Unaffiliated Directors of Mutual Funds, 115 U. PA. L. Rev. 1058 (1967). See also id. at 1071 n.32.

170 The SEC Mutual Fund Report at 127 indicates that on those rare occasions when a fund changes advisers, it is usually through sale of control by the adviser.

171 The most recent attempt was the introduction of S. 2704, the bill which led to the 1966 Hearings. This bill would have amended federal securities legislation to exempt bank-operated CIF's from the Investment Company Act, substituting regulation by the Comptroller of the Currency. It is reprinted at 1966 Hearings 2-19.

172 For the argument that operation of a CIF violates these two sections, see notes $89-109,114-30$ and accompanying text supra. 